\title{
ENTRE LIVROS E JORNAIS: UM PANORAMA DA PRODUÇÃO DOS
}

\section{JORNALISTAS-ESCRITORES}

\author{
Arthur Breccio Marchetto ${ }^{1}$
}

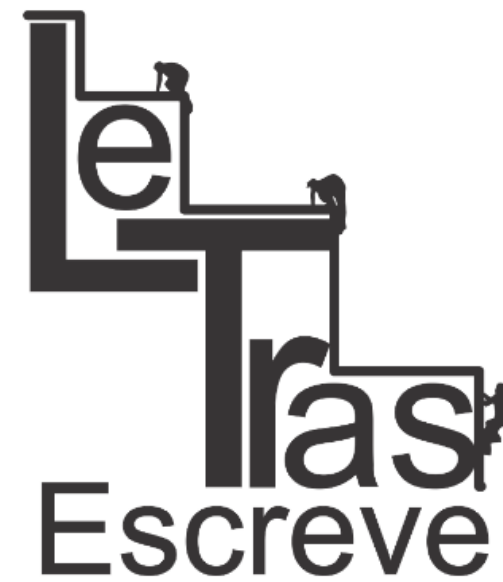

(ISSN 2238-8060)

\begin{abstract}
The paper presents a bibliographical review on the approximations and distances between journalism and literature, referring mainly to the work of journalist-writers. The retake is organized in five periods: the beginnings of Brazilian printed publications, the organization of the intellectual field, the modernization of the literary field, the intellectual production in the dictatorship and, mainly, the reorganization of the production made by journalist-writers after several changes caused by the rise of digital media. The objective of the article is to establish an overview on the history of intellectual production located in the thin space between journalism and literature.
\end{abstract}

Keywords: Literature; Journalism; Communication; Printed media; Digital media.

\section{Introdução}

A Literatura e o Jornalismo brasileiro são campos que dialogaram intensamente por toda história, fosse pela proximidade ou pela busca do distanciamento: nascidos da mesma prensa, a literatura já foi a única fonte de mão-de-obra qualificada para o jornalismo, com pro-

\footnotetext{
${ }^{1}$ Jornalista, Mestrando em Comunicação Social pela Universidade Metodista de São Paulo (UMESP), Bolsista CAPES. E-mail: arthur.marchetto@gmail.com
} 


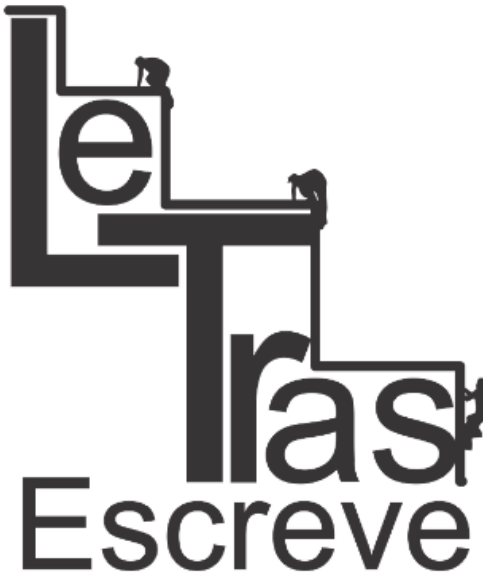

(ISSN 2238-8060) fissionais que auxiliaram a formação do campo; por sua vez, o jornalismo já foi a única fonte de renda para escritores que não encontravam um mercado editorial nacional rentável e tampouco eram herdeiros ou de famílias tradicionais.

As aproximações e os distanciamentos podem ser divididos em cinco períodos: o primeiro abarca os anos de 1808 até 1830, quando nascem as primeiras publicações impressas brasileiras e há uma forte presença dos publicistas. De 1840 até a década de 1910, o segundo momento é marcado pela transição do sistema de publicação: de burgueses compromissados com a independência para intelectuais republicanos preocupados com a literatura. O terceiro período é o da modernização da imprensa e do campo literário que, nas décadas de 1920 até 1950, terminou o processo de modernização. O movimento muda de rumo durante a ditadura, dos anos 1960 até 1980, quando há um crescimento de escrita de ficção, inclusive por jornalistas. Por fim, o último período tem início na década de 1990 e persiste até os dias de hoje, quando há um distanciamento nas experiências entre imprensa e jornalismo, além de uma mudança nas engrenagens singulares do fazer e consumir de cada campo.

Diante do um cenário repleto de vozes que anunciam fins, permanências e mudanças nos moldes de livros, jornais e leituras, o texto trará uma revisão bibliográfica dos períodos citados acima. É um panorama dos diálogos entre jornalismo, a literatura e seus jornalistas-escritores, com a intenção de apontar perspectivas passíveis de serem seguidas ao tratar da produção intelectual no Brasil, fosse ela presente em um dos campos abordado ou em ambos.

\section{Primórdios (1808 - 1830)}

Até o começo do século XIX a produção literária brasileira era fei- 


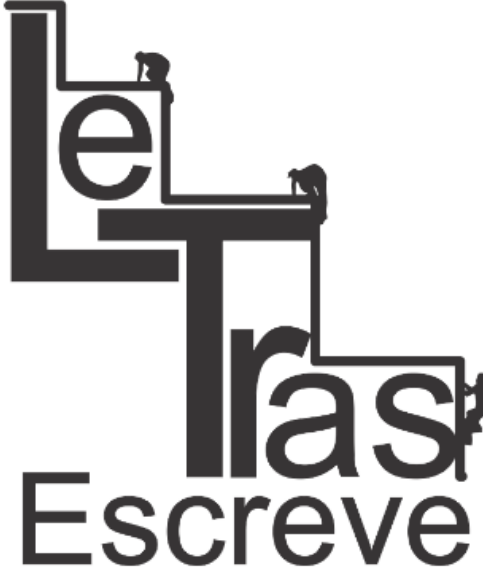

(ISSN 2238-8060)

ta sob o que Alfredo Bosi (1994, p.11) chamou de "complexo colonial de vida e de pensamento": os textos brasileiros escritos no período colonial eram também permeados por códigos literários europeus". Por isso, a produção realizada no Brasil era considera híbrida, era luso-brasileira. A emancipação da criação da literatura nacional veio com a mesma prensa que imprimiu o primeiro jornal publicado em solo brasileiro, a Impressão Régia. Com o objetivo principal de publicar documentos oficiais, o decreto da Impressão incluía a impressão de livros e outras obras, além da criação de um Conselho de Censura Prévia.

O principal gênero literário desenvolvido nesse período foi o jornalismo político, o responsável pelo estabelecimento do primeiro contato do escritor com seu público leitor. No entanto, o relacionamento ocorreu de maneira controversa, longe das escrituras e perto do ouvido. Em um espaço entre a oralidade e os clássicos europeus, o intelectual, enquanto pessoa pública, girava entre auditórios, palanques e púlpitos o que não formou um público de leitores, mas de auditores (COSTA, 2005, p.229-230). Além disso, outros fatores se tornaram agravantes para a baixa fertilidade da literatura no período. Como o objetivo da produção intelectual era auxiliar no processo de independência brasileira, a literatura era vista como produção supérflua, já que não promovia nenhuma mudança política.

Dois jornais tiveram destaque dentro desse período. 0 primeiro deles foi a Gazeta do Rio de Janeiro. Inaugurado em 10 de 1808, ele foi o primeiro jornal a ser impresso no Brasil e, com um perfil de propaganda estatal, o conteúdo do jornal "não passava da reprodução de atos oficiais, de elogios e reverências à família real, e de textos traduzidos de jornais europeus. Até 1814, acompanhava-se também o andamento da guerra que se desenrolava na Europa" (SCHWARCZ; 
STARLING, 2005, p.183). O segundo, foi o Correio Braziliense e caé considerado o primeiro jornal brasileiro. Publicado pela primeira vez meses antes da Gazeta, o jornal era editado na Inglaterra pelo exilado Hipólito da Costa e circulava clandestinamente no território brasileiro: "Sem meias palavras, muito bem informado, livre de censura e com inspiração iluminista, Hipólito redigia notícias, resumos analíticos, comentários críticas sobre os acontecimentos políticos da época" (SCHWARCZ; STARLING, 2005, p.184).

\section{Intelectuais profissionalizados (1840 - 1910)}

A perspectiva começa a mudar quando, com o fim do Conselho

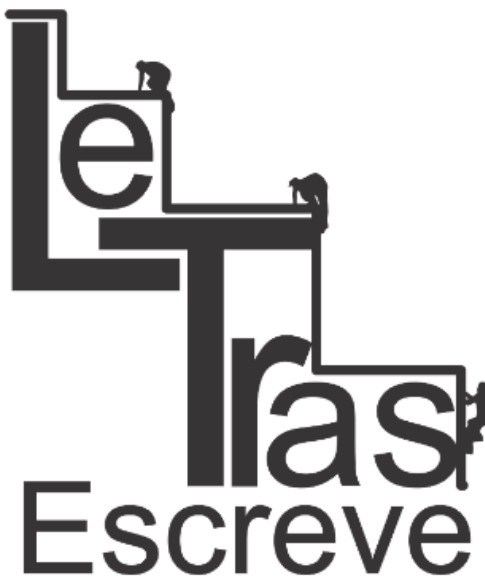

(ISSN 2238-8060) da Censura Prévia e o golpe da maioridade, em 1840, os jornais oficiais - e o clandestino Correio Braziliense - passam a "disputar leitores com folhas, gazetas, pasquins, periódicos de todos os tipos, que nasciam e morriam em poucos meses" (COSTA, 2005, p.224). O perfil dos jornais e pasquins também se modificaram. Menos revolucionários e agressivos, derem lugar ao novo homem letrado. O destaque proporcionado pela imprensa alterou o papel social do escritor: "políticos, militares, médicos, advogados, engenheiros, jornalistas ou simplesmente funcionários públicos, todos buscavam na criação poética ou ficcional o prestígio definitivo que só a literatura poderia lhes dar" (BOURDIEU apud COSTA, 2005, p.28).

Os filhos ou herdeiros "de famílias abastadas do campo, que iam receber instrução jurídica (raramente, médica) em São Paulo, Recife e Rio (...), ou com filhos de comerciantes luso-brasileiros e de profissionais liberais, que definiam, grosso modo, a alta classe média do país" eram os que calcavam o caminho das letras. Eram poucos os nascidos em famílias pobres que conseguiam alcançar o sucesso, como Teixei-

https://periodicos.unifap.br/index.php/letras

Macapá, v. 8, n. I, Io sem., 2018 


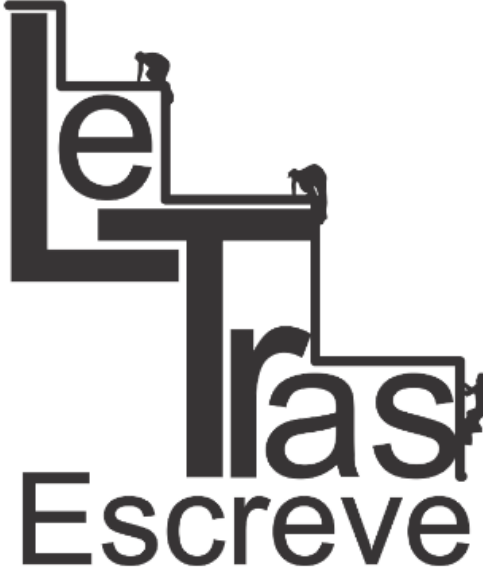

(ISSN 2238-8060) ra Coelho, o primeiro escritor de folhetim no Brasil (BOSI, 1994, p.92).

Assim, o período de profissionalização dos intelectuais tentou substituir a lógica do artista interessado apenas em ganhos simbólicos, representada pela elite intelectual, pela do "artista que deseja viver de seu talento, e que, portanto, precisa ter lucros reais com seu trabalho" (COSTA, 2005, p.26), geralmente vivida pela classe média ou baixa. Apesar da existência do primeiro estrato até os dias de hoje, o movimento de profissionalização fez com que a presença do segundo grupo fosse majoritária, principalmente quando a imprensa se mostrou como fonte de subsídio.

Vista muitas vezes como um mal necessário pelos jornalistasescritores do período, a imprensa deu ao jornalista a possibilidade de receber salário e ter um público leitor. Em uma "nova forma de dependência econômica, o jornalismo tem, por outro lado, um efeito libertador, oferecendo a jovens sem diploma ou renda a possibilidade de viver de seu próprio trabalho intelectual" (COSTA, 2005, p.27). A engrenagem funcionava muitas vezes como um ciclo retroalimentado: o aumento da população escolarizada, o crescimento e a democratização do mercado de bens culturais desenvolvia a imprensa numa sociedade que formava jovens que, com aspirações literárias, tentariam trilhar o difícil caminho de viver da arte - pela imprensa. Foram poucos os escritores-jornalistas que trilharam o caminho e alcançaram o sucesso que almejavam. Tanto por isso, Machado de Assis se tornou um exemplo: "mulato, pobre, órfão e epilético", Assis entrou no cenário literário da mesma maneira que outros escritores negros da época, pela "porta de serviço: o jornalismo" (COSTA, 2005, p.28) e passou a servir como um mito de inspiração.

No cenário, o folhetim foi um dos gêneros mais importantes. Além de ser o espaço dos jornalistas-escritores, foi um impulsionador

https://periodicos.unifap.br/index.php/letras

Macapá, v. 8, n. I, Io sem., 2018 


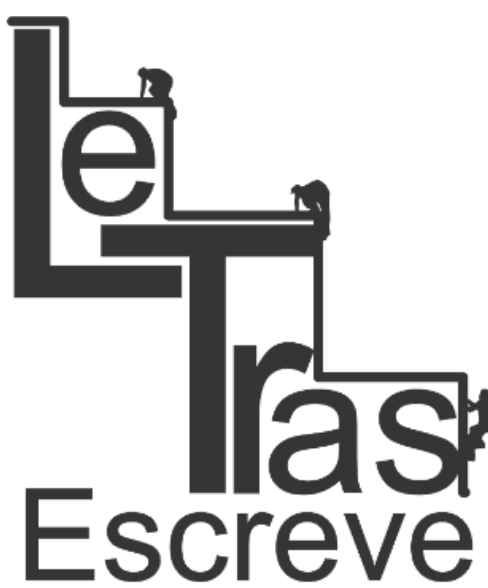

(ISSN 2238-8060)

de vendas dos jornais, responsável pela formação de um público leitor brasileiro e lançou diversos escritores, como José de Alencar e o próprio Machado de Assis (COSTA, 2005). A história dos textos de Teixeira Coelho serve de ilustração do fenômeno: inspirado na subliteratura francesa, seus textos tinham linguagem simples e atingiam um grande público iletrado e menos favorecido. Os leitores, com poucas opções de entretenimento, viam no folhetim a melhor opção e aumentavam a vendagem dos jornais. No entanto, a produção não tinha fronteiras delimitadas. Segundo Coutinho (1999, p.125), o "foIhetim era a crônica, mas também a novela ou o romance, quando publicado em jornal" (COUTINHO, 1999, p.125).

Foi José de Alencar quem criou parâmetros com seu folhetim de crônicas, Ao correr da pena, quando modificou a impressão do um espaço como um vale-tudo. Por meio do seu trabalho no jornal, Alencar adquiriu prestígio social: os jornalistas já eram considerados homens de letras e não escritores sem sucesso. Mas não tardou para o modelo de ascensão pela imprensa se tornar gasto e a possibilidade de ganhar dinheiro com trabalho intelectual crescer em outras áreas. Ao mesmo tempo, a divisão entre literatura e jornalismo se tornava cada vez mais marcada:

\begin{abstract}
A dicotomia arte e dinheiro faria o campo literário (da arte pela arte) se constituir, no Brasil, em oposição ao jornalismo (da pena de aluguel), embora a ele vinculado. E o modelo ideal (aqui quase irreal) de escritor em tempo integral, em distinção ao de trabalhador braçal (ou melhor, industrial) do jornalismo (COSTA, 2005, p.33).
\end{abstract}

No entanto, durante a virada do século, mesmo que distintos, os dois campos ainda precisavam dividir a mão-de-obra: o motivo não era mais o do sustento de escritores, mas a necessidade de contratação de profissionais capacitados em acompanhar e aperfeiçoar a lógi-

https://periodicos.unifap.br/index.php/letras

Macapá, v. 8, n. I, Io sem., 2018 


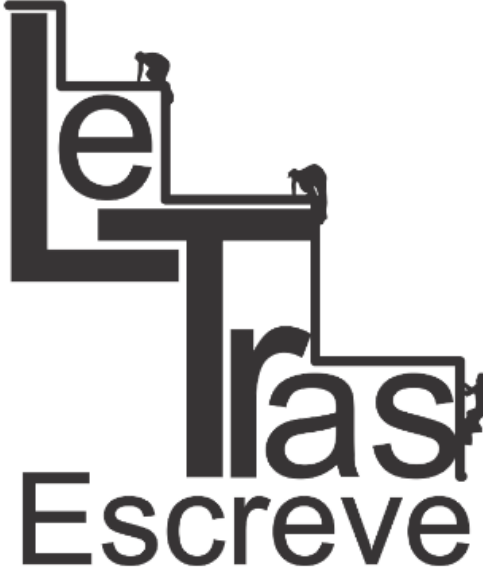

(ISSN 2238-8060) ca de trabalho dos jornais. Por isso, o jornalismo teve que buscar nomes na literatura, como João do Rio que, ao transitar entre as duas esferas, tornou-se pioneiro nas reportagens e no jornalismo investigativo brasileiro: o escritor utilizava "o questionamento das fontes, a circulação por diversos bairros em busca de diversidade, o uso privilegiado das descrições in loco" como método de trabalho de seus textos, atividades que estruturaram apuração moderna (COSTA, 2005, p.42). João do Rio era um exemplo de escritor que cumpria as demandas de reportagens, que cresciam em detrimento das ficções, e caminhava com naturalidade entre os dois campos.

As concessões que os escritores deviam fazer para transitar nas duas áreas e ascender social e economicamente não eram apenas de formatos, mas também de posicionamentos ideológicos. Segundo Miceli (2001), nesse momento, a opção pela carreira literária estava diretamente ligada às mudanças negativas no status social. A morte ou o abandono do pai-provedor e/ou a perda de poder aquisitivo da família e/ou a incapacidade de conseguir trabalhos pelo acometimento de doenças graves, como a tuberculose, obrigava o filho a utilizar o capital cultural e as relações sociais adquiridas antes para garantir uma posição política subalterna, mas remunerada - era subalterna pois os cargos disponíveis eram ligados à grande imprensa, às instituições políticas ou às organizações partidárias e serviam à manutenção da dominação oligárquica.

Como principal catalizadora de cultura, a grande imprensa "constituía a principal instância de produção cultural da época e que fornecia a maioria das gratificações e posições intelectuais" (MICELI, 2001, p.17). Os jornais eram representantes de grupos poderosos e, por isso, os escritores "viam-se obrigados a identificar-se com os interesses políticos do jornal para o qual trabalhava; o êxito que alcançavam

https://periodicos.unifap.br/index.php/letras

Macapá, v. 8, n. I, Io sem., 2018 
por meio de sua pena poderia Ihes trazer salários melhores, sinecuras burocráticas e favores diversos" (MICELI, 2001, p.55).

Um nome de destaque nesse momento foi Lima Barreto, que fazia parte da elite do capital cultural, mas economicamente proletária. Diferente de João do Rio, Lima Barreto não submeteu seu trabalho ao prazer da burguesia e do mercado e, dentro do jornalismo, trilhou um caminho de poucas concessões: escrevia textos de entretenimento para a burguesia, chamado de jornalismo sorriso. No fim de sua vida, Barreto era alcoólatra e não tinha fama ou dinheiro (COSTA, 2005), mas, junto de Monteiro Lobato e Euclides da Cunha, sua produção marcava o pré-modernismo.

\section{Pré-Modernismo e Modernismo (1920 - 1950)}

O pré-modernismo configurou o cenário literário brasileiro até a Semana de 1922 e foi marcado pelo consumo de tendências europeias dentro da elite cultural, que tentava trilhar um caminho nacional de expressão, enquanto outros escritores marcavam a literatura. Foram poucos os literatos que desfrutaram da busca Modernista:

Nesse clima, só um grupo fixado na ponta de lança da burguesia culta, paulista e carioca, isto é, só um grupo cuja curiosidade intelectual pudesse gozar de condições especiais como viagens à Europa, leitura dos derniers cris ${ }^{2}$, concertos e exposições de arte, poderia renovar efetivamente o quadro literário do país (BOSI, 1994, p.333).

Enquanto faziam suas experimentações, de 1917 até 1922, os modernistas "travaram conhecimento com as várias poéticas de pósguerra e constituíram-se como um grupo jovem e atuante no meio literário paulista" (BOSI, 1999, p.333). Ao mesmo tempo, a literatura

\footnotetext{
${ }^{2}$ Do francês, a expressão significa a "última sensação", a novidade de alguma coisa.
} 


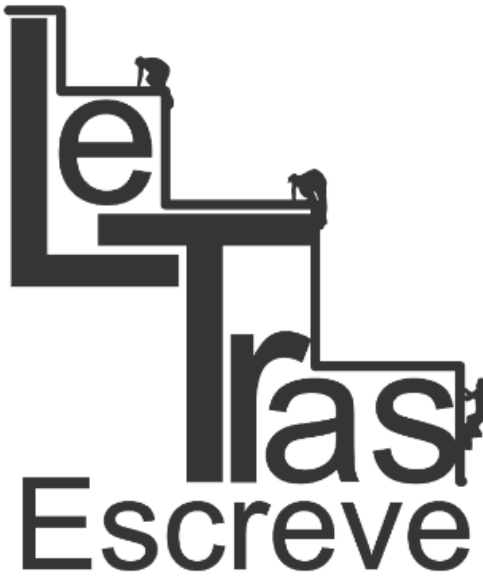

(ISSN 2238-8060)

brasileira era marcada por três personagens externos ao grupo: o primeiro deles era Euclides da Cunha e seu ensaísmo social. Segundo Alfredo Bosi (1999, p.308-309), “o moderno em Euclides está na seriedade e boa-fé para com a palavra. Contrariamente ao vício decadentista de jogar com os sons e as formas à deriva de uma sensualidade fácil”. A característica influenciaria romancistas na década de 1930, como Graciliano Ramos. O segundo era Lima Barreto e a "descida de tom, que permitiu à realidade entrar sem máscara no texto literário" (BOSI, 1994, p.318). De maneira desambiciosa, as cenas cotidianas, a burocracia, os tipos de café e de jornal, além de diversas outras características outrora excluídas, passavam a permear as linhas dos romances.

Por fim, o último ator foi Monteiro Lobato. Presente antes, durante e depois do da Semana de Arte Moderna, "Lobato foi o primeiro escritor brasileiro a conceber a literatura como mercadoria" (COSTA, 2005, p.75). Ao notar a dominação do produto estrangeiro no cenário nacional, Monteiro Lobato montou estratégias para vender livros, como a abertura de livrarias, assinaturas de livros ou vendas em casas comerciais, e faliu diversas vezes, mas não desistiu.

Ao mesmo tempo, a produção intelectual de Lobato era avessa as ideias Modernista. O conflito nasceu das perspectivas que se assentavam na vida literária brasileira, tanto no cenário nacional quanto no interior do grupo modernista:

Sua opção [de Monteiro Lobato] por uma literatura "desliteraturizada", que revela a tentativa de atingir um público mais amplo, foi duramente criticado por intelectuais como Mário de Andrade, que o chamava, entre outras coisas menos leves, de mercenário (...). Cada qual foi moderno a seu modo. Mário, ligando-se ao projeto de arte pela arte. Lobato, à sedução da arte como mercadoria. Um, ao modelo europeu; outro, ao americano. Em comum, pode-se dizer que os dois buscaram nas raízes da cultura popular um modelo livre do academicismo da

https://periodicos.unifap.br/index.php/letras

Macapá, v. 8, n. I, Io sem., 2018 
A Semana de 22 teve um forte papel histórico, mas pouca continuação. Segundo Sérgio Miceli (2001, p.97), a produção dos intelectuais "modernistas em matéria de decoração, de vestuário, de ética sexual etc. inscrevem-se com maior acerto na história da importação dos padrões de gosto da classe dirigente ligada à expansão do café do que na história da produção intelectual", uma vez que a cultura europeia contaminava as obras e só permita a interpretação pela elite letrada que estava habituada ao cenário e ao contexto.

Mas, ao olhar o momento fora perspectiva vanguardista, é possível observar o estabelecimento de um mercado editorial nacional

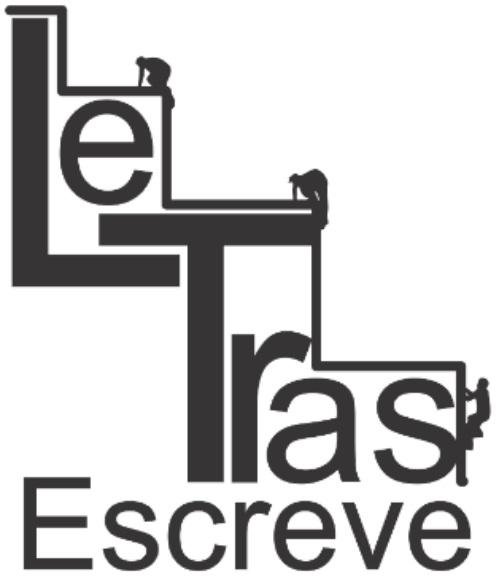

(ISSN 2238-8060) mais abrangente. Quando a crise de 1929 e a 2a Guerra Mundial impediu, entre outras coisas, a importação de livros, o mercado editorial brasileiro investiu em traduções e gerou a produção de autores nacionais, mesmo que alguns escrevessem adaptações de textos estrangeiros.

\begin{abstract}
Embora possa se registrar um aumento na participação dos autores brasileiros no mercado do livro, não se pode afirmar que tenha havido uma autonomização no plano cultural seja em relação à Europa, seja em relação aos Estados Unidos, uma vez que a produção nacional nesse período era insuficiente para cobrir a demanda relativa aos principais gêneros em ascensão, como, por exemplo, os manuais de viver, os policiais, os livros técnicos, etc., ou então era bastante incipiente, no caso dos romances femininos (MICELI, 2001, p.148).
\end{abstract}

A situação provocou uma profissionalização estrutural no mercado editorial, que adquiria novas máquinas, e uma especialização na mão de obra, visto no surgimento de funções como revisão e tradução. Assim, as artes gráficas e as estratégias de venda foral alteradas e, devido à modernização, surgia "um pequeno grupo de escritores profissionais, os romancistas" (MICELI, 2001, p.149). Nesse estrato só 


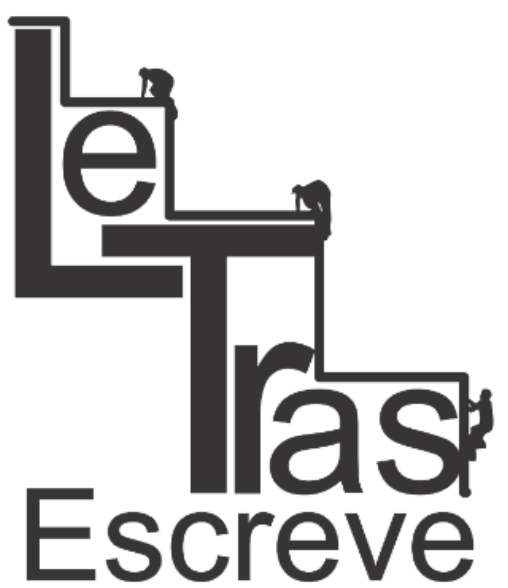

(ISSN 2238-8060)

possuiu autonomia intelectual os que se dedicaram aos romances de alta vendagem, como Érico Verissimo ou Jorge Amado, e foram suas carreiras que traçaram rumos para a geração seguinte de escritores: "Realismo e linguagem despojada de rebuscamentos: essas seriam as regras que escritores brasileiros, como Graciliano Ramos, tentariam implantar a partir de então, não só na literatura como nas redações dos jornais" (COSTA, 2005, p.92). Além disso, a consciência histórica de problemas relacionados à resistência da estrutura oligárquica do poder no Brasil - a aristocracia do café deu lugar à burguesia industrial - permeou pensamentos de escritores como o próprio Graciliano Ramos, Carlos Drummond de Andrade e José Lins do Rego.

Tanto a ruptura literária dos anos 1920 e 1930 como a sistematização do jornalismo nos anos 1950 tinham a intenção de enxugar o texto: eliminar as marcas de intelectualidade e os adjetivos:

\begin{abstract}
Portanto, não se deve estranhar que escritores identificados com esse projeto tenham tomado para si o trabalho de chefe da redação, como Drummond, ou do copidesque, como Graciliano, ou ainda o repórter, redator, diretor de suplementos literários e até dono de jornais e revistas como Oswald, reescrevendo o jornalismo, assim como a ficção e a poesia que se faziam até então (COSTA, 2005, p.100).
\end{abstract}

Com o estabelecimento do modelo de concisão e objetividade, de aproximação dos costumes e da oralidade, a cisão definitiva entre literatura e jornalismo se promovia. Como elemento decisivo, a imprensa nacional configurava-se cada vez mais como uma corporação industrial e adotava padrões de redações estadunidenses, como o Manual de Redação. Dentro do corpo de jornalistas, uma voz destacava-se com mais intensidade contra esse movimento: Nelson Rodrigues e o jornalismo fictício e sensacionalista

https://periodicos.unifap.br/index.php/letras

Macapá, v. 8, n. I, Io sem., 2018 


\section{Ditadura, censura e a explosão ficcional (1960 - 1980)}

Nelson Rodrigues costumava a chamar copidesques de idiotas da objetividade e é dele o título de último grande folhetinista brasileiro. Depois de uma extensa trajetória no jornalismo, Rodrigues viveu a censura no Estado Novo e na ditadura, "acompanhou de perto a substituição do jornalismo político pela imprensa sensacionalista, sua derrocada em nome da objetividade, a crescente influência do rádio, da TV, do cinema" (COSTA, 2005, p.241) e, até sua morte, Nelson defendeu o sensacionalismo e a ficção jornalística. Devido ao posicionamento, Rodrigues não escrevia mais no corpo dos jornais, mas em uma coluna diária chamada $A$ vida como ela é... . Segundo Cristiane Costa (2005, p.128), "a ideia era que escrevesse a partir de fatos reais. Mas o escritor preferiu inventar tudo, preenchendo sua coluna com os mesmos personagens típicos da Zona Norte carioca que faziam parte de suas reportagens e de seu teatro".

Todavia, Nelson era uma exceção e, dos anos 1960 até a década de 1980, o Jornalista foi destaque na produção de literatura ficcional, fora das páginas dos periódicos: "não só porque quase toda a ficção (ISSN 2238-8060) do período foi escrita por gente que vivia o dia-a-dia das redações (...), mas também porque o jornalista, assim como o escritor, o padre e o guerrilheiro, foi o grande protagonista da ficção do período" (COSTA, 2005, p.131). O destaque na produção e o aumento de vendagem e qualidade ocorreram, principalmente, por causa da ditadura militar, da padronização dos textos e de uma "rara confluência entre o projeto dos escritores e o interesse dos leitores" (COSTA, 2005, p.133).

O jornalismo deu uma posição diferenciada ao olhar do intelectual, que sentiu o regime militar em cima de um muro: de um lado a 


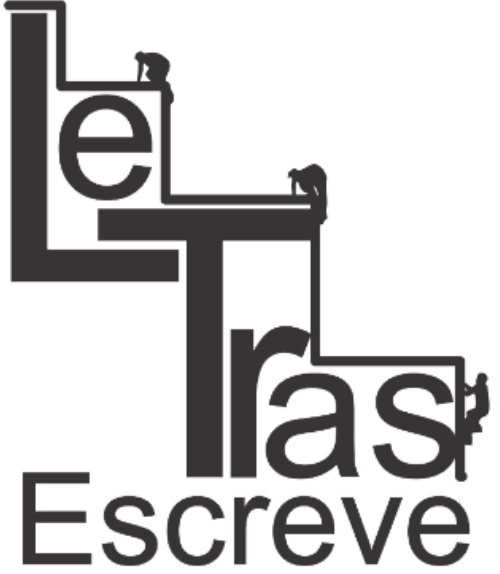

(ISSN 2238-8060)

elite, representada pelo patrão a quem se submetia, e do outro o oprimido, o qual via todos os dias nas ruas. Ressentidos e frustrados, alguns jornalistas se revoltaram com "os limites éticos de uma imprensa censurada" (COSTA, 2005, p.154) e passaram a informar por meio de livros, menos censurados, utilizando técnicas dos romancesreportagens, influenciados pelo new jornalism estadunidense, ou do realismo-mágico, movimento forte na América Latina, principalmente contra regimes autoritários.

A literatura brasileira adquiria um "estilo de narrar brutal, se não intencionalmente brutalista" (BOSI, 1999, p.434), principalmente a partir de 1964 até 1974. Os livros escritos no momento mais sombrio da ditadura não seguiam apenas a contraideologia, preparando o leitor para combater o Estado autoritário e a mídia mentirosa, mas também seguiam o caminho do capital estrangeiro e da globalização, abordando "as ilusões de onisciência e onipotência do eu burguês, pondo a nu os seus limites e opondo-Ihe a realidade da diferença" (BOSI, 1999, p.436).

Quando o modelo capitalista consolidou sua supremacia sobre a ditadura brasileira, o projeto do jornalismo literário foi frustrado. 0 primeiro fator foi a normatização do texto: quando o jornalismo nos EUA se adequou ao ritmo moderno de leitura, "investindo em infográficos coloridos, muitas fotos, cobertura jornalística centrada em serviços, celebridades, TV e esportes, interatividade e atualização das notícias em web sites e, acima de tudo, matérias curtas básicas e puramente informativas. (COSTA, 2005, p.270), o Brasil copiou os moldes e eliminou de suas páginas o desenvolvimento estético dos textos.

Outros fatores, como a falta de uma estrutura socioeconômica que incentivasse o contato com a produção intelectual, como a pre-

https://periodicos.unifap.br/index.php/letras

Macapá, v. 8, n. I, Io sem., 2018 
carização do ensino público, "a entrada em cena de uma ficção inteiramente voltada para as massas: a televisão" (COSTA, 2005, p.165) e a queda da censura, que trouxe o conteúdo exclusivo dos livros para as páginas dos jornais, agravaram o sufocamento do jornalismo literário aqui desenvolvido. Por fim, “a globalização marcou o abandono do projeto nacionalista que nasceu com o romantismo, teve seu momento marcante entre as décadas de 30 e 50 e sustentou praticamente toda a literatura dos anos 60 e 80" (COSTA, 2005, p.165).

\section{Atualidadea (1990 - )}

Ainda que em caminhos diferentes há algum tempo, o abafamen-

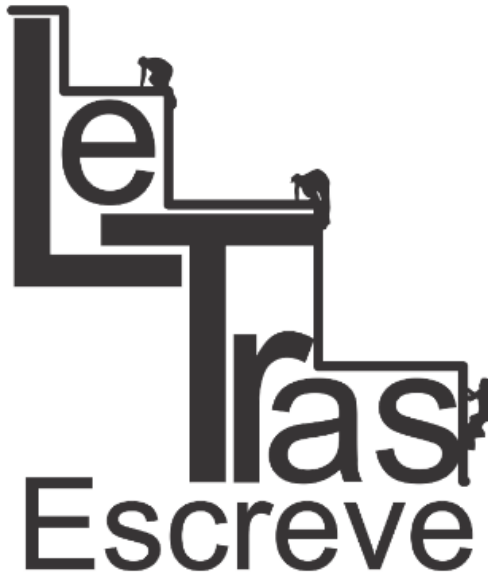

(ISSN 2238-8060) to das ideias nacionalistas aprofundou a cisão entre literatura e jornalismo. No caso da imprensa, as empresas assumiram que seu objetivo em tempos modernos era ser porta-voz da sociedade civil, mas se tornou refém da opinião pública. Sua postura passou a ser passiva e dava ao seu público o que supunha que ele queria. Como grande influenciadora, a opinião pública gerou um "jornalismo ansioso, impaciente, definindo linhas erradas de apuração, não se preocupando com a verdade, atropelando a objetividade jornalística e os direitos individuais" (NASSIF, 2003, p.3-4).

A falta de dinheiro também contaminou a imprensa e revelou outra inversão na sua relação com e literatura: "enquanto o escritor se profissionaliza(...), as relações de trabalho na imprensa tornaram-se cada vez mais precárias" (COSTA, 2005, p.189). Com o passar dos anos, a presença do jornalista-escritor se tornou cada vez mais rara nas redações, uma vez que elas foram esvaziadas pelas demissões em massa e nas trocas da mão-de-obra cara por jornalistas terceirizados ou estagiários contratados. O processo, gradual e agravado por uma 


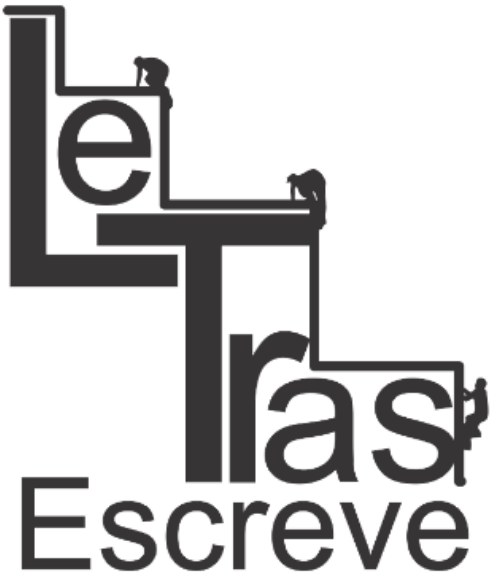

(ISSN 2238-8060) grande gama de fatores relacionados, começou nos anos 1990 e teve o seu ápice na virada do século.

Com o aumento do consumo de televisores, a relação das empresas de comunicação com a informação passou a ser técnica e pragmática. A TV se tornou uma concorrente desleal dos veículos impressos e, como reação, a maioria deles implantou modificações, como o encurtamento de textos e um maior desenvolvimento gráfico - no caso dos jornais diários, também perderam o caráter comunitário e passaram ter valor de mercado conforme sua rapidez e alcance da distribuição. José Arbex Jr. (2005, p.58) destacou que "quanto mais rapidamente um jornal era impresso, e quanto maior seu alcance, maior a sua importância para os interesses econômicos privados que o sustentavam", o que garantia a publicidade, parte mais importante de seu sustento.

Porém o fim da paridade do dólar com o real, em 1999, e a recessão econômica desestabilizaram as corporações jornalísticas e

levaram a um aumento de custos de produção (de papel, equipamentos, software e programações importadas de TV) e financeiros (já que com o Plano Real, em 1994, boa parte dos órgãos de imprensa tinha se endividado para a instalação de novos parques gráficos), sem a contrapartida do aumento das verbas publicitárias das empresas de comunicação (COSTA, 2005, p.190).

Os computadores também enxugaram as redações. Como possuíam funções automáticas, eles substituíram mão-de-obra, e a informatização do texto na plataforma facilitou sua criação: já que os textos não eram mais à mão, a escrita se tornou mais instantânea e passiva de correções em tempo real. Por fim, a popularização dos PCs não só modificou a escritura, mas a leitura dos textos também. "Se a criação é facilitada, essa agilidade também induz a um texto mais curto e de

https://periodicos.unifap.br/index.php/letras

Macapá, v. 8, n. I, Io sem., 2018 


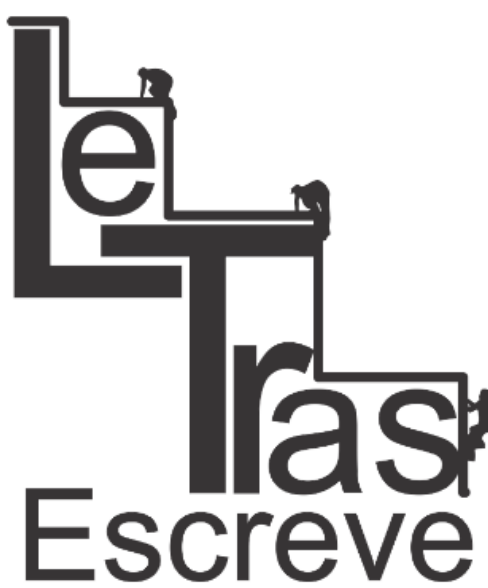

(ISSN 2238-8060) leitura mais rápida, com eventuais supressões de letras e expressões, dando origem a novos dialetos" COSTA, 2005, p.197). O fato de ser "possível conciliar formas lineares e não-lineares na narrativa multimídia. E atribuir ao mesmo indivíduo as funções de autor, editor, divulgador e distribuidor" (COSTA, 2005, p.198) provocou mudanças, ainda incertas, no consumo de textos jornalísticos, mas também nos textos literários.

No entanto, o trajeto da literatura começa quando 'Que país é este?” deixa "de ser a grande questão que movia a literatura brasileira. O novo-perfil do jornalista escritor a partir dos anos 90 pode ter muito a ver com isso" (COSTA, 2005, p.165). Antes que a saída dos jornalista-escritores das redações fosse consolidada, eles mudaram seu perfil de trabalho, trocando editorias de política, cotidiano e economia pela de cultura. A escolha possibilitou desenvolvimento intelectual focado no campo e manteve nomes no meio público, mas não sem prejuízos: em primeiro lugar, caso publicado, o livro do jornalista dificilmente saía em outros jornais, pelo nome associado à concorrência; em segundo, o espaço de publicação também foi usado para troca de favores entre editores, críticos e jornalistas.

O comportamento novo, de reflexão da natureza da literatura dentro dos jornais ao invés de uma busca por experiências e a construção de um repertório de vivência, impactou as temáticas abordadas pela produção literária: “A questão não é mais política, mas existencial e estética" (COSTA, 2005, p.174-175). O desenvolvimento da natureza da literatura nas páginas dos livros acompanhou a discussão do espaço urbano, principalmente pela transformação das capitais em polos de produção editorial, e da violência, que manteve sua presença, mas, diferente da época do governo militar, tratava da omissão do Estado "como regulador das demandas e choques entre as

https://periodicos.unifap.br/index.php/letras

Macapá, v. 8, n. I, Io sem., 2018

184 


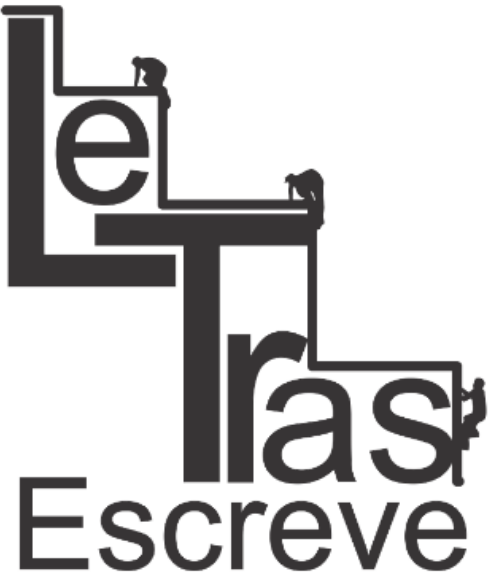

(ISSN 2238-8060)

diversas classes, seja por culpa do mercado global, dos fundos monetários internacionais ou até da própria globalização do crime do narcotráfico" (COSTA, 2005, p.184).

A preocupação com o fazer da literatura foi presente não só na abordagem temática, mas na formação acadêmica. Por falta de um curso de Escrita Criativa no Brasil, a formação em Comunicação Social passou a ser comum nos escritores - indicativo de uma maioria de escritores pertencente à uma elite ou, pelo menos, à uma classe privilegiada.

Apesar da reversão na profissionalização/precarização dos campos, descrita acima, o fim dos anos 1990 e o início dos anos 2000 aproximou a literatura e o jornalismo na reflexão sobre o texto produzido, na busca pelo público e, principalmente, no questionamento financeiro:

\begin{abstract}
Se o leitor já não precisa pagar para ter acesso ás matérias de um jornal, e se mesmo os grandes órgãos de imprensa têm como prática usar as informações atualizadas pelos sites uns dos outros, muitas vezes dispensando a intermediação das agências de notícias, quem vai custear o trabalho jornalístico? E, por vias tortas, a literatura brasileira? (COSTA, 2005, p.199).
\end{abstract}

Com o passar dos anos, a produção jornalística manteve seu sistema produtivo e o enxugamento das redações e buracos no orçamento agravaram nas grandes empresas de comunicação. Otavio Frias Filho (2016) identificou um profundo paradoxo nas relações entre público e notícias: um alto consumo de notícias e de informação na web, mas sem credibilidade e sem um ecossistema econômico capaz de sustentar uma produção de grande porte. A popularização das redes sociais Facebook, YouTube e Twitter, alterou a circulação da informação pela sociedade. Hoje, a possibilidade de produzir e midiatizar as notícias não é exclusiva dos grandes meios de comunicação,

https://periodicos.unifap.br/index.php/letras

Macapá, v. 8, n. I, Io sem., 2018 
mas é de qualquer cidadão minimamente capacitado.

A internet possibilitou a criação de diversas inciativas de jornalismo comunitário, militante, autoral e de entretenimento. É possível ver iniciativas de jornalismo independentes bancadas quase em sua totalidade por crowdfunding ${ }^{3}$, dependendo de doações e fundos de empresas, mas é um modelo que não se adequa aos grandes conglomerados. A queda nos preços da publicidade na internet provocou um rombo no orçamento da grande imprensa que, entre paywalls ${ }^{4} \mathrm{e}$ assinaturas digitais, ainda não conseguiu ser fechado.

Mas, por fim, Frias Filho é otimista em relação ao futuro da leitura e do próprio sustento do jornalista.

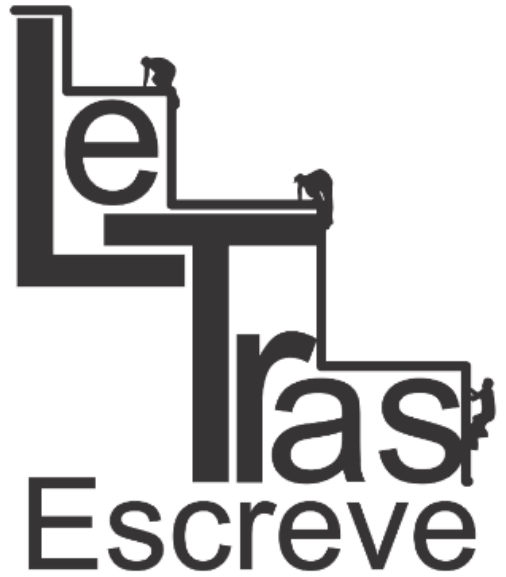

(ISSN 2238-8060)

A equação econômica que permita sustentar o jornalismo como serviço independente e criterioso, movido pelo espírito público, ainda está por ser solucionada. (...) Mas os avanços na escolaridade e o próprio aumento da classe média em escala mundial são motivo para confiança. Preparam, por assim dizer, a demanda, um leitorado cada vez mais numeroso e com mais discernimento (FRIAS FILHO, 2016).

Tal confiança não é consenso. Ao tratar da leitura, Zoara Failla (2014) acredita que a cultura digital não estimula o interesse dos adolescentes nos livros, que prefere passar o tempo de lazer nas redes. Além disso, Failla (2014) acredita que o efeito editorial de romances de doenças, os sick-lits, ou dos livros de autoajuda para adolescentes criou leitores temporários, que, devido à baixa qualidade dos livros lidos, não seguirão com leituras futuras,

Em outra ponta, Nestor García Canclini (2014) defende que, na cultura digital, os indivíduos leem a todo momento: notícias, redes

\footnotetext{
${ }^{3}$ Crowdfunding é o ato de arrecadar dinheiro pela internet. Alguns sites, como Catarse e Padrim, são plataformas conhecidas e especializadas nesse tipo de arrecadação.

${ }^{4}$ O paywall é um recurso que impede a visualização de todo o conteúdo do site para nãoassinantes. Alguns restringem por número de visualizações e outros com material exclusivo..
}

https://periodicos.unifap.br/index.php/letras

Macapá, v. 8, n. I, Io sem., 2018 
sociais, ou romances. Canclini (2014) acredita que é preciso questionar a qualidade do que se lê e não a quantidade, fugir da perspectiva mercantil da leitura e buscar os hábitos de consumo da comunidade de leitura.

\begin{abstract}
A observação etnográfica e histórica indica que o tempo de leitura de notícias, relatos, informações sobre as ciências e as técnicas não foi reduzido. A grande modificação reside em que ela não é feita principalmente nas mídias tradicionais, nem nos recintos destinados a essas finalidades (salvo a casa e a escola, que permanecem), nem da forma linear e com objetivos de distinção simbólica e cultural geral atribuídos à leitura e à escrita nos séculos XIX e XX. Não podemos nos limitar a desenhar enquetes com as perguntas que interessam aos editores, livreiros e quem se formou lendo livros (CANCLINI, 2014).
\end{abstract}

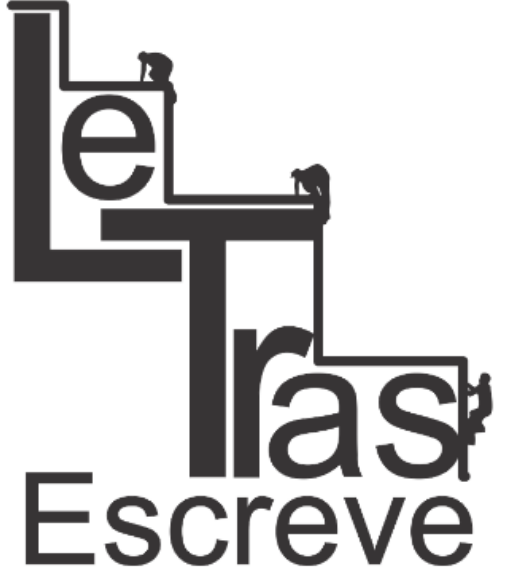

(ISSN 2238-8060)

Os exemplos da existência de uma cultura de leitura fora dos meios tradicionais é vivida por jovens e adolescentes "nos festivais de poesia em voz alta, na criação literária em blogs, nas edições independentes e nos audiolivros e páginas digitais que estimular a ver de outro modo a cena da escrita e da leitura". O pesquisador Roger Chartier (2014) tem uma visão semelhante, ao comentar sobre a grande quantidade de festivais literários no Brasil: as "manifestações não devem nos deixar esquecer das questões graves do país, do analfabetismo, da baixa porcentagem de leitores de livros, nem da pobreza. (...) [Mas] elas são sinais de uma vitalidade cultural impressionante".

Como visto na criação literárias dos blogs, Chartier (2014) também ressalta a valorização que o "papel criador do leitor" teve, muito devido à maleabilidade dos textos no ambiente digital. Tais possibilidades alteram três estruturas da literatura moderna:

primeiramente, a singularidade da escrita, atribuída a um sujeito particular; em segundo lugar, a originalidade da obra, sempre passível de reconhecimento, qualquer que seja a sua forma

https://periodicos.unifap.br/index.php/letras

Macapá, v. 8, n. I, Io sem., 2018 
de publicação; por fim, a propriedade literária, patrimonial e moral, que justifica o copyright (CHARTIER, 2014).

Essas modificações trouxeram a possibilidade de uma escrita aberta, coletiva e anônima, longe da estática do impresso, mas que fragmentou o livro. A coerência dos textos, responsável pela organização de um livro, é perdida quando um texto é transposto para o ambiente digital. Chartier (2014) comenta que a lógica da rede é de "um mundo de fragmentos descontextualizados, destacados pela vontade do leitor de qualquer totalidade (do livro, do jornal ou da revista), totalidade essa que ele não é obrigado, nem mesmo convidado a perceber", e gera, no ato da leitura, uma percepção de associações efêmeras entre textos e imagens e separa, pela primeira vez na história, o livro-obra e o livro-objeto. "Ela coloca em questão os critérios de percepção e compreensão dos textos" (CHARTIER, 2014).

Em outra ponta, os escritores passam a se profissionalizar fora da imprensa e sustentam seu trabalho no mercado publicitário, nos roteiros de televisão, já que "a lei que obrigou a produção de $30 \%$ do conteúdo nacional nos canais a cabo abriu um enorme mercado" (COSTA, 2016) $)^{5}$ e, graças ao forte canal que as redes sociais se tornaram para tornar escritores celebridades, com os cachês de eventos literários e a autopublicação.

Todavia, a autopublicação ainda é uma medida controversa, já que pode atrapalhar o trabalho do escritor:

Além de buscar formas criativas de viabilizar seu projeto literário, um autor que se pretende multitasking deve conhecer todos os estágios da publicação de um livro impresso e digital, passando pela produção de conteúdo, escolha do suporte, plataforma de publicação e formas de comercialização. Ao final, deve ainda decidir as estratégias que irá adotar para ganhar visibilidade e se destacar em um mercado hiperinflado de lança-

${ }^{5}$ Entrevista concedida por e-mail no segundo semestre de 2016.

https://periodicos.unifap.br/index.php/letras

Macapá, v. 8, n. I, Io sem., 2018 
mentos, competindo com os departamentos de marketing e divulgação das grandes editoras. Ao assumir uma série de funções que não eram tradicionalmente suas, desperdiça o tempo que poderia ser gasto no trabalho criativo com templates e planilhas. Mas, com isso, pode ganhar autonomia e controle total de sua carreira (COSTA, 2014).

Segundo Leyla Perrone-Moisés (2016), é o momento para traçar os caminhos que desejamos e, quando refletir sobre a existência de uma literatura pós-moderna, afirma: “Nossa época é o momento de pensar sobre o passado recente e de criticar os caminhos do presente. Só depois dessa fase poderão surgir 'pensamentos novos'. E deixaremos de vê-la como 'pós', para vê-la como 'pré' alguma coisa que ainda ignoramos" (PERRONE-MOISÉS, 2016, p.48-49).

\section{Considerações Finais}

Em momentos turbulentos, como o apresentado no artigo, é difícil identificar onde as bases serão firmadas e em que pontos elas cairão, mas permite diversos questionamentos que guiam as observações dos alicerces. No que tangencia a imprensa, destaca-se que as grandes empresas ainda procuram uma maneira de firmar-se no ambiente digital, tanto no modelo de negócios quanto nas possibilidades do texto que a linguagem digital proporciona. Além disso, os modelos de negócios experimentados pelo jornalismo independente, como a Agência Pública, não são replicáveis e, apesar de possibilitarem o desenvolvimento autoral de jornalistas, levantam uma preocupação financeira pela carência que têm com fundos e doações de grandes empresas.

Enquanto isso, a efemeridade dos livros nas livrarias e as novas possibilidades de escrita e leitura trazem à tona perguntas referentes à qualidade dos livros: se os livros saem em tanta abundância e du-

https://periodicos.unifap.br/index.php/letras

Macapá, v. 8, n. I, Io sem., 2018 


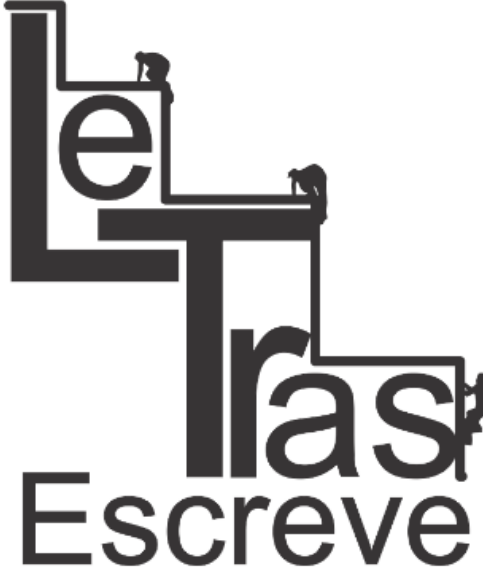

(ISSN 2238-8060) ram tão pouco, que tipo de qualidades terão? Sem mão-de-obra experiente, quem tratará de veicular e destacar a crítica dos livros dentro dos meios de comunicação? Ou as redes sociais estruturam um espaço suficientemente organizado para esse tipo de conteúdo?

Enfim, é possível perceber que a figura do escritor-jornalista desapareceu com o enxugamento das redações e a profissionalização da área literária, principalmente pelas feiras, eventos e o mercado audiovisual, mas o perfil do escritor parece ter se mantido - homem, branco, classe média, mas pertencente à uma elite cultural e ligado às capitais urbanas. Os fenômenos de autopublicação e das redes sociais alteraram a agenda dos escritores e permitiram que eles fossem conhecidos e ganhassem dinheiro pelo cachê dos festivais, cursos e eventos, mas que tipo de literatura é feita quando é preciso passar tempo investindo na sua imagem nas redes? Perde-se o tempo do exercício da escrita, obrigatório no exercício jornalístico e dos roteiros de televisão, e prejudicando a produção literária?

As respostas e as soluções só poderão ser dadas a longo prazo, mas, como destacado acima, esse é o momento de reflexão e do alinhamento das intenções: é preciso pensar quais são as respostas que queremos dar para essas perguntas e traçar o percurso até elas.

\section{Referências}

ARBEX JUNIOR, José. Showrnalismo: a notícia como espetáculo. São Paulo: Casa Amarela, 2005.

BOSI, Alfredo. História concisa da literatura brasileira. São Paulo: Cultrix, 1999.

CANCLINI, Néstor García. Quanto ou como se lê? Refazer as perguntas. Revista Observatório Itaú Cultural, São Paulo, n.17, p.168-177,

https://periodicos.unifap.br/index.php/letras

Macapá, v. 8, n. I, Io sem., 2018 
ago./dez.2014.

CHARTIER, Roger. A leitura como prática cultural. Revista Observatório Itaú Cultural, São Paulo, n.17, p.19-26, ago./dez.2014. Entrevista concedida a Revista Observatório Itaú Cultural.

COSTA, Cristiane. Pena de aluguel: escritores jornalistas no Brasil 1904-2004. São Paulo: Companhia das Letras, 2005. . As novas funções do autor na era digital. Revista Observatório Itaú Cultural, São Paulo, n.17, p.178-191, ago./dez.2014.

COUTINHO, Afrânio. A literatura no Brasil. 5. Ed. rev. E atual. - São Paulo: Global, 1999.

FAILLA, Zoara. Retratos de um jovem leitor. Revista Observatório Itaú Cultural, São Paulo, n.17, p.76-95, ago./dez.2014.

FRIAS FILHO, Otavio. O paradoxo da mídia. In: Folha de S.Paulo, 28/02/16: Folha 95 Anos-2.

MICELI, Sergio. Intelectuais à brasileira. São Paulo: Companhia das Letras, 2001.

NASSIF, Luís. O jornalismo nos anos 90. São Paulo: Futura, 2003.

PERRONE-MOISÉS, Leyla. Mutações da literatura no século XXI. São (ISSN 2238-8060) Paulo: Companhia das Letras, 2016.

SCHWARCZ, Lilia Moritz; STARLING, Heloisa Murgel. Brasil: uma biografia. São Paulo: Companhia das Letras, 2015.

Enviado em 31/07/2017

Aceito em 23/01/2018 